\title{
STRATEGI MERESPON PUJIAN \\ PADA PEMBELAJAR BAHASA JEPANG: KAJIAN KOMPARATIF DENGAN PENUTUR ASLI
}

\author{
Rosi Rosiah* \\ Universitas Muhammadiyah Yogyakarta \\ rosi.rosiah@umy.ac.id
}

\begin{abstract}
This study compares the use of responding praise strategies by 20 subjects of Japanese language learners and 20 native speakers. Using DTC (Discourse Complemente Test) as an instrument which consists of 18 situations, the data of 360 sentences were then analyzed using a semantic formula from the concept of Korsatianwon Sayan (2003) that divides the response of praise into 15 strategies, namely: gratitude, approval expression, happy expression, praise upgrade, disagreement, suspect intent, comment acceptance, reassigment, empty, return, question, change topic, scale down, laugh and shame or shock. In conclusion, many Japanese language learners respond to praise with the strategy of rejecting praise. This is in accordance with the concept of 'refusing praises' in the East, which means humbling ourselves. Meanwhile, the native speakers of Japanese respond to praise with 'being grateful' strategy. This is in accordance with the conception of 'thank you' in the West to respond to praises, which aims to maintain the positive face of the other person.
\end{abstract}

Keyword: Strategies, Compliment Responses, Japanese Learners

\section{Intisari}

Penelitian ini membandingkan penggunaan strategi merespon pujian dengan menggunakan subyek 20 orang pembelajar bahasa Jepang dan 20 orang penutur asli. Instrumen yang digunakan adalah DTC (Discourse Complemente Test) yang terdiri dari 18 situasi. Data sebanyak 360 kalimat kemudian dianalisis menggunakan semantic formula dari konsep Korsatianwon Sayan (2003) yang membagi respon pujian ke dalam 15 strategi, yaitu: terima kasih, ungkapan persetujuan, ungkapan bahagia, praise upgrade, disagreement, mencurigai maksud, comment acceptance, reassigment, ungkapan kosong, return, question, mengganti topik pembicaraan, scale down, tertawa dan malu atau terkejut. Kesimpulannya, pembelajar bahasa Jepang banyak merespon pujian dengan strategi menolak pujian. Hal ini sesuai dengan konsep Timur, yaitu menolak pujian yang mengandung makna merendah. Sedangkan penutur asli bahasa Jepang banyak merespon pujian dengan strategi berterima kasih. Hal ini sesuai dengan konsepsi ucapan terima kasih di Barat untuk merespon pujian yang bertujuan untuk menjaga positive face lawan bicara.

Kata Kunci: strategi, merespon pujian, pembelajar bahasa Jepang 


\section{Pendahuluan}

Ungkapan dalam bahasa Jepang

banyak sekali jenisnya. Salah satu ungkapan yang sering digunakan dalam kehidupan sehari- hari adalah ungkapan memuji. Penutur asli bahasa Jepang sering mengucapkan kata-kata pujian dalam percakapan sehari-hari. Alangkah baiknya jika seorang pembelajar bahasa Jepang dapat memahami kata-kata pujian dan merespon dengan tepat sesuai konteks dan situasinya.

Wolfson (dalam Rosiah, 2017) Mengatakan bahwa dalam pergaulan antar sesama, manusia mempunyai fungsi utama sebagai pencipta dan pemegang hubungan antar manusia. Memuji, dari segi kesopanan, merupakan salah satu contoh kesopanan yang mempunyai makna positif. Dalam komunikasi, memahami cara merespon atau menanggapi pujian dengan benar sangat penting agar dapat tercipta komunikasi yang efektif dan terhindar dari kesalahpahaman.

Banyak penutur asli bahasa Jepang yang merepon pujian dengan strategi menghindar, sesuai dengan apa yang diutarakan oleh Maruyama (dalam Rosiah, 2017) bahwa merespon pujian dengan menolak sebuah pujian merupakan konsepsi Timur. Untuk membuktikan apakah penutur asli bahasa Jepang merespon pujian dengan menolak, maka dibutuhkan penelitian lebih lanjut.

Sebagai representasi dari kasus yang terdapat dalam dunia pendidikan bahasa Jepang di Indonesia pada jenjang perguruan tinggi, dan untuk menjelaskan hal tersebut secara ilmiah, maka penulis membandingkan respon terhadap pujian yang digunakan pembelajar bahasa Jepang dengan penutur asli bahasa Jepang.

\section{Landasan Teori}

Strategi Merespon Pujian

Ditinjau dari konsep positive politeness yang dikemukakan oleh Brown dan Levinson (dalam Langscope, 1994), menerima pujian dapat dikategorikan sebagai strategi kesantunan. Konsep ini lebih cenderung mengacu pada pandangan Barat, yaitu penerimaan terhadap pujian dikategorikan sebagai sarana untuk memberikan ruang bagi positif face pemberi pujian. Artinya, dengan menerima pujian seseorang dikatakan menghormati dan menghargai pemberi pujian karena ia 
telah sepakat bahwa yang diungkapkan oleh pemberi pujian itu benar dan baik.

Sebaliknya, Levine dkk (dalam Nur \& Wisnu, 2005), menyatakan:

"Most peoples enjoy receiving compliment, only that we have to understand there are culturally different ways of responding to compliment".

Hal ini sejalan jika dikaitkan dengan konsepsi Timur yang cenderung melakukan penolakan terhadap pujian dengan pandangan bahwa hal tersebut merepresentasikan kerendahan hati penerima pujian.

Pada dasarnya, untuk merepon pujian yang diberikan, seseorang dihadapkan pada sejumlah pilihan untuk menjaga komunikasi agar tetap harmonis. Cara merespon yang dipilihpun harus disesuaikan dengan konteks yang ada, karena interpretasi respon tersebut berbeda antara kultur yang satu dengan kultur yang lain.

Korsatianwon Sayan (2003) membagi kategori khusus respon dalam bahasa Jepang ke dalam tiga kategori, yaitu: menerima, menolak, dan mitigasi dan kemudian dibagi ke dalam 15 strategi, yaitu: terima kasih (感謝 (kansha)), ungkapan persetujuan (賛同発言(sandou hatsugen)), ungkapan bahagia (喜び発言 yorokobi hatsugen)), praise upgrade (誉めの追加 (home no tsuika)) (menambahkan katakata untuk meningkatkan pujian), disagreement (不賛成発言 (fusansei hatsugen)) (penolakan dengan memberikan komentar kontradiktif dengan objek pujian), keraguan terhadap maksud seseorang (意図一の疑い (ito $e$ no utagai)), comment acceptance (情報的 コメント (jyohoteki komento)), reassignment (シフト(shifuto)), ungkapan kosong（控えめな発言 (hikaemena hatsugen)), return (ほめ返し(homegaeshi), question（的確さへの疑問・とまどい (tekikakusa e no gimon, tomadoi)), mengganti topik pembicaraan (話題の切 り替え (wadai no kirikae)), scale down (ほ めの軽減 (home no keigen)), tertawa (笑い (warai)), dan malu atau terkejut (照れ ・ 驚 き発言 (tere, odoroki hatsugen)). 


\section{Metodologi Penelitian}

Metode Penelitian yang digunakan dalam penelitian ini adalah metode deskriptif. Adapun pengertian even dari penelitian deskriptif adalah penelitian yang digunakan untuk menggambarkan, menjabarkan suatu fenomena yang terjadi saat ini dengan menggunakan prosedur ilmiah untuk menjawab masalah secara aktual (Sutedi, 2009).

Subjek dalam penelitian ini adalah pembelajar bahasa Jepang semester delapan Universitas Pendidikan Indonesia sebanyak 20 orang dan penutur asli bahasa Jepang sebanyak 20 orang yang merupakan mahasiswa dari Kinjou Gakuin dari Nagoya University.

Data yang terdiri dari 18 situasi diperoleh dengan menggunakan DTC (Discourse Complemente Test). Dari DTC diperoleh data kalimat respon terhadap pujian sebanyak 360 kalimat yang kemudian dianalisis dengan menggunakan semantic formula dari teori Korsatianwon Sayan (2003).

\section{Hasil dan Pembahasan}

Data yang diperoleh dari DTC di atas, ditabulasikan ke dalam tabel di bawah ini:

Tabel 1. Tabel distribusi strategi merespon pujian pembelajar bahasa Jepang dan penutur asli bahasa Jepang

\begin{tabular}{|c|c|c|c|c|c|c|}
\hline \multirow[t]{2}{*}{ No. } & \multirow{2}{*}{$\begin{array}{l}\text { Kategori } \\
\text { Respon }\end{array}$} & \multirow[t]{2}{*}{ Strategi respon } & \multicolumn{2}{|c|}{$\begin{array}{c}\text { Pembelajar Bahasa } \\
\text { Jepang }\end{array}$} & \multicolumn{2}{|c|}{$\begin{array}{l}\text { Penutur Asli } \\
\text { Bahasa Jepang }\end{array}$} \\
\hline & & & & $P$ & & $P$ \\
\hline \multirow[t]{4}{*}{1.} & \multirow[t]{4}{*}{ Menerima (Ac) } & Terima Kasih & 112 & $30,8 \%$ & 133 & $36,9 \%$ \\
\hline & & Ungkapan Persetujuan & 20 & $5,5 \%$ & 26 & $7,2 \%$ \\
\hline & & Ungkapan Bahagia & 19 & $5,2 \%$ & 45 & $9,4 \%$ \\
\hline & & Praise Upgrade & 7 & $1,9 \%$ & 27 & $7,5 \%$ \\
\hline \multirow[t]{2}{*}{2.} & \multirow[t]{2}{*}{ Menolak (Re) } & Disagreement & 114 & $31,4 \%$ & 44 & $12,2 \%$ \\
\hline & & $\begin{array}{l}\text { Keraguan Terhadap Maksud } \\
\text { Seseorang }\end{array}$ & 1 & $0,3 \%$ & 2 & $0,5 \%$ \\
\hline
\end{tabular}




\begin{tabular}{|c|c|c|c|c|c|c|}
\hline \multirow[t]{9}{*}{3.} & \multirow[t]{9}{*}{ Mitigasi (Ev) } & Comment Acceptance & 25 & $6,3 \%$ & 17 & $4,7 \%$ \\
\hline & & Reassigment & - & - & 3 & $3,3 \%$ \\
\hline & & Ungkapan Kosong & 4 & $1,1 \%$ & 6 & $1,7 \%$ \\
\hline & & Return & 6 & $1,6 \%$ & 15 & $3,9 \%$ \\
\hline & & Question & 44 & $12,1 \%$ & 10 & $2,8 \%$ \\
\hline & & Mengganti Topik Pembicaraan & 1 & $0,3 \%$ & 1 & $0,3 \%$ \\
\hline & & Scale Down & 5 & $1,4 \%$ & 41 & $11,4 \%$ \\
\hline & & Tertawa & - & - & 5 & $1,4 \%$ \\
\hline & & Malu Atau Terkejut & 4 & $1,1 \%$ & 2 & $0,6 \%$ \\
\hline
\end{tabular}

Sumber: Data Primer

Dari tabel di atas dapat diambil kesimpulan bahwa pembelajar bahasa Jepang banyak menggunakan strategi disagreement (31,4\%), diikuti oleh terima kasih (30,8), Menanyakan maksud (12,2\%), comment acceptance (6,4\%), ungkapan persetujuan (5,6\%), ungkapan bahagia (5,3\%), praise upgrade $(1,9 \%)$, return $(1,7 \%)$, scale down (1,4\%), ungkapan kosong $(1,1 \%)$, malu atau terkejut $(1,1 \%)$, dan strategi yang kemunculannya paling sedikit ialah strategi keraguan terhadap maksud seseorang dan strategi mengganti topik pembicaraan $\quad(0,3 \%)$ Teridentifikasi strategi disagreement (31,3\%), menunjukan bahwa pembelajar bahasa Jepang mengikuti konsep Timur dalam merespon pujian. Mengemukakan ketidaksetujuan terhadap pujian yang diberikan berarti merepresentasikan kerendahan hati.

Sedangkan penutur asli bahasa Jepang banyak merespon pujian dengan menggunakan strategi terima kasih $(36,9 \%)$, diikuti oleh disagreement $(12,2 \%)$ diikuti oleh scale down (11,4\%), ungkapan bahagia (9,4\%), praise upgrade (7,5\%), ungkapan persetujuan (7,2\%), comment acceptance $(4,7 \%)$, return (3,9\%), reassignment (3,3\%), question (2,8\%), ungkapan kosong $(1,7 \%)$, tertawa $(1,4 \%)$ malu atau terkejut (0,6\%), dan strategi yang kemunculannya paling sedikit ialah strategi keraguan terhadap maksud seseorang dan strategi mengganti topik pembicaraan $(0,3 \%)$.

Tingginya jumlah penutur asli bahasa Jepang yang merespon pujian 
dengan berterima kasih membuktikan bahwa orang Jepang menganut konsepsi Barat dalam merespon pujian. Dengan menerima pujian dapat dikategorikan sebagai strategi kesantunan dan sarana untuk memberikan ruang bagi positif face pemberi pujian, artinya dengan menerima pujian seseorang dikatakan menghormati dan menghargai pemberi pujian karena ia telah sepakat bahwa apa yang dikemukakan oleh pemberi pujian itu benar dan baik.

Berikut adalah contoh-contoh percakapan yang dapat menjelaskan hal tersebut:

\section{Strategi Terima Kasih}

Pembelajar bahasa Jepang menggunakan strategi terima kasih (30,8\%) untuk merespon pujian hampir dalam seluruh situasi, namun situasi yang paling banyak menggunakan strategi ini adalah pada saat lawan bicaranya adalah seorang teman. Strategi ini merupakan strategi merespon pujian kedua yang sering digunakan oleh pembelajar bahasa Jepang. Sedangkan penutur asli menggunakan strategi ini sebanyak $36,9 \%$, lebih banyak jika dibandingkan dengan pembelajar bahasa Jepang. Pembelajar bahasa Jepang menggunakan strategi ini untuk merespon seluruh situasi. Yang paling banyak digunakan adalah ketika merespon pujian yang disampaikan oleh dosen yang akrab maupun tidak, juga oleh teman yang akrab maupun tidak. Contoh ungkapan yang digunakan untuk merespon pujian adalah sebagai berikut:

Situasi \#13, ketika jam baru PBJ dipuji oleh teman dekat.

(PBJ 1)

A : A! Atarashii tokei dane. line... Anata ni yoku niau yo!

B : Arigatou. Un, atarashii yo. Kawaii kara katta.

Terjemahan:

A : Wah, jamnya baru ya. Bagus. Sangat cocok dengan anda.

B : Terima kasih, iya ini baru. Saya beli karena bagus.

Pada data PBJ 1 di atas penutur membuka dengan ungkapan "arigatou" sebagai penanda bahwa penutur menerima pujian yang diberikan. Dan untuk menambahkan lagi penerimaan terhadap pujian penutur mengungkapkan "un atarashiiyo" sebagai tanda persetujuan dengan apa yang diungkapkan oleh pemberi pujian (complementer). 
Contoh ungkapan yang disampaikan oleh penutur asli bahasa Jepang (PABJ) pada situasi \#1, dengan situasi anda dipuji oleh dosen pria akrab mengenai hasil ujian, seperti pada respon berikut ini:

\section{(PABJ 1}

A Sensei : $\quad$ kono aida no tesuto, yoku dekimashita ne.

B : Arigatou gozaimasu. Konkai no tesuto de ii ten o toreta nomo sensei no Terjemahan : goshidou no okage desu.

GuruA : Tes waktu itu, hasilnya bagus sekali.

B : Terima kasih. Saya mendapatkan nilai yang bagus pada tes kali ini pun berkat bimbingan bapak.

Pola pada PABJ 1 memperlihatkan perbedaan sosial, yaitu ditunjukan dengan penggunaan kata panggilan sensei yang menunjukan status lawan bicara lebih tinggi dari pada penutur.

\section{Strategi Ungkapan Persetujuan}

Strategi ungkapan persetujuan merupakan salah satu strategi respon terhadap pujian yang menunjukan penerimaan secara langsung terhadap pujian yang diberikan dan setuju terhadap pujian yang diberikan. Pembelajar bahasa Jepang menggunakan strategi ini untuk merespon pujian dalam situasi \#13 sebanyak sembilan tuturan, situasi \#3, situasi \#9, dan situasi \#14 masing-masing dua tuturan, dan yang terakhir situasi \#1, situasi \#2, situasi \#15 dan situasi \#16 masingmasing satu tuturan.

Penutur asli bahasa Jepang menggunakan strategi ini untuk merespon pujian dalam situasi \#13 sebanyak 10 tuturan, situasi \#16 empat tuturan, kemudian situasi \#3 tiga tuturan, situasi \#15 dua tuturan dan yang paling sedikit situasi \#1, situasi \#8 dan situasi \#18 satu tuturan.

Contoh ungkapan yang digunakan untuk merespon pujian pada situasi \#13. jam baru anda dipuji oleh teman, adalah sebagai berikut:

(PBJ 2)
A : A! Atarashii tokei dane. line... anata ni yoku niau yo!
B : Soudayo. Kinou kattanoyo. Zutto hoshikatta kara, te ni irete, hontou ni yokatta.

Terjemahan:

A : Wah. Jamnya baru ya. Bagus... Sangat cocok dengan kamu.

B : lya, saya belikemarin. Saya membelinya karena sudah lama mengingingkannya.

Pada data PBJ 2 terlihat penutur menerima pujian yang diberikan dengan menggunakan kalimat “soudayo”. Dan juga menambahkan komentar yang berisi 
informasi untuk menambah lancarnya berkomunikasi dan sebagai penambah bahwa penutur menerima pujian tersebut.

Berikut adalah contoh ketika PABJ mendapat pujian untuk jam barunya:

A : A! Atarashii tokei dane. line... Anata ni yoku niau yo!

B : Sousou, sakki katta no!!

Terjemahan:

A : Wah, jamnya baru ya. Bagus... Sangat cocok dengan kamu.

B : Betul. Baru beli barusan.

Berdasarkan percakapan di atas, penutur mengemukakan kesamaan pendapat dengan apa yang dikemukakan oleh pemberi pujian dengan menggunakan kata "sousou".

\section{Strategi Ungkapan Bahagia}

Strategi ini merupakan salah satu strategi respon terhadap pujian yang menunjukan penerimaan secara tidak langsung terhadap pujian yang diberikan dengan menunjukan kebahagian. Pembelajar bahasa Jepang merespon pujian dengan menggunakan strategi ini pada saat merespon pujian pada situasi \#12 enam tuturan, situasi \#4, situasi \#5, situasi \#9, stausi \#10, situasi \#15, dan situasi \#16 dua tuturan, dan yang terakhir situasi \#2 satu tuturan. Sedangkan penutur asli bahasa Jepang menggunakan strategi ini untuk merespon pujian dalam situasi \#12 sebanyak 11 tuturan, situasi \#18 sembilan tuturan , situasi\#10 enam tuturan, situasi \#1 dan situasi\#15 empat tuturan, situasi \#4 tiga tuturan, situasi \#5, situasi \#9 dan situasi \#11 dua tuturan, dan yang terakhir situasi \#2 dan situasi \#16 satu tuturan.

Berikut adalah contoh Situasi \#4 : pada saat PBJ dipuji oleh dosen wanita yang dekat dengan anda sangat senang membaca hasil karya anda.

$(\mathrm{PBJ} 3)$

A Sensei: Anata ga kaita kenkyuu
houkoku wo yomimashita.
Yoku kakimashita ne. Naiyou
ga yokumatomatta
B $\quad$ Soudesuka... Sonna fuu ni
iwareru to, ureshii desu wa.

Terjemahan:

Guru A: Saya sudah membaca laporan penelitian anda. Tulisannya bagus. Isinya sangat lengkap.

B : Oh ya? Senangnya dipuji seperti itu.

Pada kalimat PBJ 3 penutur mengunakan kalinat 'soudesuka' untuk menanyakan kembali isi pujian karena penutur tidak menyangka akan dipuji, 'soudesuka' bisa juga punya arti terkejut dan tidak percaya, namun yang menjadi inti dari ungkapan itu adalah ungkapan "sonna 
fuu ni iwareru to, ureshii desu" yang mengungkapkan kebahagiaan karena telah diberikan pujian.

Contoh ungkapan yang disampaikan oleh penutur asli bahasa Jepang untuk respon Situasi \#4: dipuji oleh dosen wanita yang dekat dengan anda sangat senang membaca hasil karya anda.

$(\mathrm{PAB} J 3)$

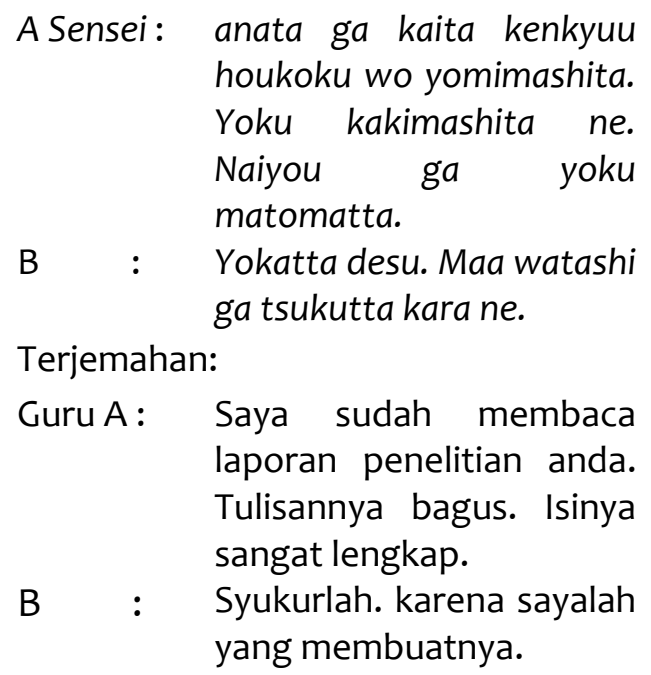

\section{Strategi Praise Upgrade}

Praise upgrade merupakan salah satu strategi respon terhadap pujian yang menunjukkan penerimaan dengan menambahkan ujaran yang menujukan bahwa pujian memang pantas diterima karena sesuai dengan keadaan. Pembelajar bahasa Jepang menggunakan strategi ini untuk merespon pujian dalam berbagai situasi, misalnya pada situasi situasi \#3 dua tuturan, situasi \#5, situasi \#10, situasi \#11, situasi \#12, situasi \#16 satu tuturan.

Berikut adalah contoh Situasi \#3: Pada saat PBJ dipuji oleh pelatih karena telah memenangkan pertandingan.

Kantoku: Anata no okage de, bokura no chi-mu ga shouri shimashita. Yoku yarimashita.

Watashi: Haha... Atarimae deshou.

Terjemahan :

Pelatih : Kemenangan tim ini semua berkat kamu. Kerja yang bagus.

Saya : Haha.. wajarlah.

Dalam kalimat PBJ 4 perasaan akrab dapat dirasakan dari pemilihan kata. Pertama-tama penutur tertawa untuk membuka perkataan dan menambahkan 'atarimae deshou' untuk mengungkapkan bahwa pujian yang diungkapkan sudah wajar dan tepat untuk diterima.

Penutur asli bahasa Jepang menggunakan strategi ini untuk merespon pujian dalam berbagai situasi, seperti pada situasi \#3 dan situasi\#13 tujuh tuturan, situasi \#8 empat tuturan, situasi \#16 tiga tuturan, situasi \#18 dua tuturan, dan yang paling sedikit situasi \#1, situasi \#4 dan situasi \#12 satu tuturan. Berikut adalah 
contoh ungkapan yang disampaikan oleh penutur asli bahasa Jepang.

Situasi \#3 Dipuji oleh pelatih mengenai usaha dalam memenangkan pertandingan.

(PABJ 4)

Kantoku: Anata no okage de, bokura no chi-mu ga shouri shimashita. Yoku yarimashita.

Watashi : Deshou. Yaru toki wa yaru yo watashi wa.

Terjemahan:

Pelatih :

Kemenangan tim ini semua berkat kamu. Kerja yang bagus.

Saya : Kan. Saya tuh kalau diminta mengerjakan pasti akan mengerjakan dengan baik.

Pada data di atas, penutur asli bahasa Jepang mengungkapkan persetujuan terhadap pujian yang diutarakan sebagai pembuka.

\section{Strategi Disagreement}

Strategi disagreement adalah respon yang diberikan berupa penolakan dengan memberikan komentar yang kontradiktif dengan dengan objek pujian tersebut. Ini merupakan strategi untuk menolak pujian. Strategi ini merupakan strategi yang paling banyak digunakan oleh pembelajar bahasa Jepang untuk merespon pujian dalam berbagai situasi. Strategi ini paling banyak digunakan dalam merespon pujian di situasi \#6 sebanyak 13 tuturan dengan lawan bicara kenalan baru, dan situasi \#8 sebanyak 11 tuturan.

Berikut adalah contoh percakapan dengan Situasi \#6: Di perpustakaan, dosen memuji PBJ karena tekun belajar.

(PBJ 5)

B Sensei : Nani o site iruno.

Anata : Raishuuno kimatsushiken no benkyoushiteorimasu.

B Sensei : Anatawa majimedane. Erai!

Anata : le, ie, hazukashii desu yo.

Terjemahan:

Guru B : Sedang Apa?

Anda : Saya sedang belajar untuk Ujian Akhir minggu depan.

Guru B : Anda sangat rajin. Hebat!

Anda : Tidak, jadi malu.

Pada data di atas, penutur menolak pujian dan menambahkan 'hazukashii' (malu) ketika mendapat pujian.

Penutur asli bahasa Jepang menggunakan strategi ini untuk merespon pujian hampir pada seluruh situasi. Strategi ini merupakan strategi ke dua yang paling banyak digunakan yang tersebar dalam situasi \#6 sebanyak 11 tuturan, situasi \#2 10 tuturan, situasi \#9 lima tuturan, situasi \#5, 
situasi \#8, dan situasi \#17 tiga tuturan, situasi \#7, situasi \#11, situasi \#16 dua tuturan, dan yang terakhir situasi \#1, situasi \#3 dan situasi \#18 satu tuturan. Contoh tuturan strategi disagreement yang digunakan oleh penutur asli bahasa Jepang adalah sebagai berikut.

Situasi \#9: PABJ Dipuji oleh teman mengenai belajar sebelum ujian.

(PABJ 6)

Anata: Kinou shiken benkyou de tetsuya dattanda. Mecha tsukareta.

PSan : Tetsuyade!? Sugoi! Kimi wa yaru toki wa yarune.

Anata: Sugokunai yo! Mainichi benkyou shiteireba tetsuya suru hitsuyou wa nai noni.

Terjemahan :

Anda : Kemarin malam belajar untuk ujian sampai begadang. Capeknya.

P : Begadang? Hebat! Kamu kalau sudah semangat pasti dikerjakan.

Anda: Tidak hebat! Kalo setiap hari belajar, tidak perlu belajar sampai tengah malam.

Pada data di atas penutur menolak pujian dengan mengatakan 'sugokunaiyo' yang berarti tidak setuju dengan apa yang diungkapkan oleh pemberi pujian. Penutur juga memberikan komentar yang berlawanan dengan apa yang menjadi objek pujian.

\section{Strategi Keraguan Terhadap Maksud Seseorang}

Strategi ini adalah strategi penolakan terhadap pujian dengan menanyakan maksud dalam memberikan pujian.

Strategi ini merupakan strategi yang paling sedikit digunakan oleh pembelajar bahasa Jepang. Hanya terlihat satu ungkapan yang termasuk ke dalam strategi ini, yaitu pada situasi \#11 Dipuji oleh teman anda, karena anda mencat rambut.

(PBJ 6)

Y Kun : $\quad$ A! Atarashii kami dane. Anata ni yokuniau yo.

$X \quad$ : Yoku niautte, mae yori motto kirei ni naru deshou.

Terjemahan:

$\mathrm{Y}$ : Wa, Rambut baru ya? Cocok sama kamu.

X : Dimaksud dengan cocok tuh, bukannya sekarang lebih cantik dari pada sebelumnya.

Pada data di atas penutur menanyakan maksud dari isi pujian.

Begitupun dengan penutur asli bahasa Jepang, penutur asli bahasa Jepang jarang sekali menggunakan strategi ini dalam merespon pujian. Penggunaan strategi ini dapat ditemukan dalam dua situasi yaitu strategi \#5 dan strategi\#16 satu tuturan. 
Berikut adalah contoh percapakan untuk Strategi \#16. Di sebuah pertemuan ada teman memuji penampilan.

$(\mathrm{PAB} J 7)$

\begin{tabular}{|c|c|c|}
\hline Tomodc & & $\begin{array}{l}\text { (Anata no namae) jyanai? } \\
\text { Kawaii. Betsujin mieruyo!! }\end{array}$ \\
\hline Anata & : & E usoda \\
\hline Terjema & & \\
\hline Teman & & $\begin{array}{l}\text { Eh itu (Nama Anda), } \\
\text { bukan? }\end{array}$ \\
\hline Anda & & $\begin{array}{l}\text { Pangling loh. } \\
\text { Ih Bohong. }\end{array}$ \\
\hline
\end{tabular}

Pada ungkapan di atas jelas sekali penutur mencurigai maksud dari pemberi pujian dan cenderung tidak mempercayai pujian yang diberikan oleh pemberi pujian.

\section{Strategi Comment Acceptance}

Strategi comment acceptance yaitu respon yang diberikan dengan cara pengalihan pujian pada objek yang dijadikan sasaran pujian dengan menceritakan kisah tentang objek tersebut.

$$
\text { Pembelajar bahasa Jepang }
$$
menggunakan strategi ini pada saat merespon pujian dalam situasi situasi \#17 sebanyak lima tuturan, situasi \#14 empat tuturan, situasi \#8, situasi \#11 tiga tuturan, situasi \#6 dua tuturan, dan yang terakhir situasi \#2, situasi \#3, situasi \#5, situasi \#13 dan situasi \#18 satu tuturan. Contoh ungkapan yang digunakan oleh pembelajar adalah sebagai berikut:

Situasi \#17. Anda dipuji oleh dosen karena menjadi sukarelawan panti jompo.

(PBJ 7)

Sensei: Anta wa ne roujinho-mu de borantia shiteirun desuka. Erai desune. Roujin nokoto, chanto kangaemasu ne.

Anata: Ahaha, iya betsu ni. Tada roujin wo miru to jiichan to baachan no koto wo tsui omoi tsuki, nanika wo tetsudaitaina tte omotte imasu.

Terjemahan:

Guru : Kamu kerja paruh waktu di rumah panti jompo? Hebat ya, memikirkan orang tua dengan baik.

Anda : Haha, tidak juga. Hanya saja apabila melihat orang tua secara tidak sadar ingat pada kakek dan nenek, jadi ingin memberikan bantuan.

Pada data di atas, di awal kalimat penutur menyatakan penolakan terhadap pujian, namun penolakan tersebut bukanlah inti dari tuturan yang diungkapkan penutur. Yang menjadi inti adalah kalimat sebelumnya dimana penutur memberikan penjelasan mengenai alasan penutur membantu orang tua.

Penutur asli bahasa Jepang menggunakan strategi ini untuk merespon 
pujian yang diberikan pada situasi \#17 empat tuturan, kemudian situasi \#16 tiga tuturan, kemudian situasi \#7, situasi \#11 dan situasi \#13 dua tuturan, dan yang terakhir situasi \#6, situasi \#8, situasi \#9, dan situasi \#14 satu tuturan. Contoh ungkapan yang digunakan oleh penutur asli bahasa Jepang, adalah sebagai berikut:

Situasi \#11. Dalam acara karya wisata kenalan teman anda memuji anda karena anda orangnya sangat humoris.

(PABJ 8)

PSan : Anata wa omoshiroi hito desu ne. Anata : Geinin mezashiteiru karane. Terjemahan:

Tuan P : Kamu orangnya humoris ya.

Anata : Cita-cita saya menjadi pelawak.

Data di atas menunjukkan penutur tidak menerima maupun menolak pujian yang diberikan melainkan cenderung menghindar dengan menceritakan kisah tentang objek tersebut.

\section{Strategi Reassignment}

Yaitu strategi respon terhadap pujian dengan cara mengalihkan topik yang dijadikan objek pujian kepada orang ketiga atau hal yang berkaitan dengan hal tersebut. Pembelajar bahasa Jepang tidak menggunakan strategi ini dalam merespon pujian.
Penutur asli bahasa Jepang menggunakan strategi ini untuk merespon pujian dalam situasi \#8, situasi \#9 dan situasi \#15 satu tuturan.

Situasi \#15. Jam tangan baru anda dipuji oleh seorang teman.

(PABJ 9)

Tomodachi: a! Atarashii tokei dane. line... Anata ni yoku niau yo!

Anata : Okaasan kara morattan dayo.

Terjemahan:

Teman : Wah! Jam tangan baru. Bagus. Cocok sekali dipakai kamu.

Anda : Dapat dari ibu.

Pada data di atas penutur menghindar dengan menyebutkan orang ke tiga yang berhubungan dengan objek. Bahwa objek yang menjadi pujian dalam hal ini jam tangan adalah pemberian dari ibu.

\section{Strategi Ungkapan Kosong}

Yang termasuk ke dalam strategi ini adalah tuturan seperti "maane" (ya begitulah). Pembelajar bahasa Jepang menggunakan strategi ini untuk merespon pujian pada situasi \#3, situasi \#8, situasi \#14 dan situasi \#6 masing-masing satu tuturan.

Situasi \#3. Dipuji oleh teman mengenai belajar sebelum ujian. 
(PBJ 8)

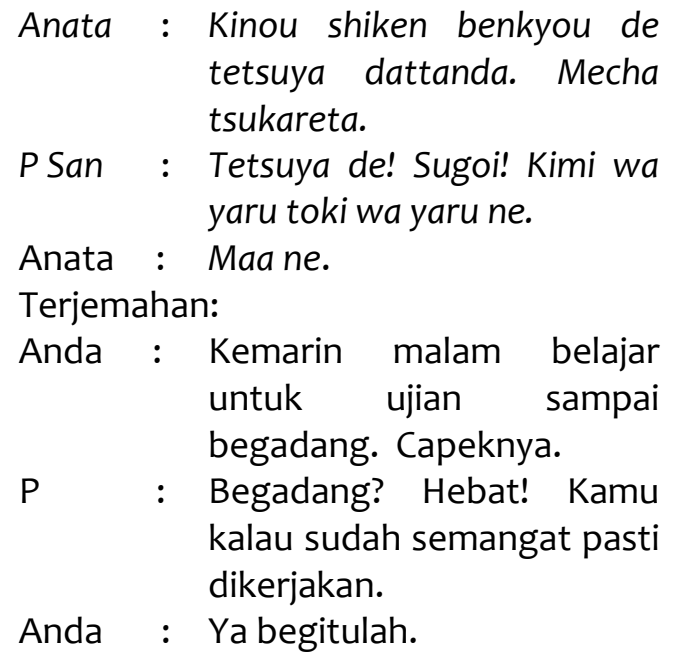

Pada kalimat di atas, penutur tidak menolak atau menerima pujian yang diberikan, tetapi lebih menghindar dengan mengucapkan “ya begitulah" yang merupakan jawaban yang dianggap sangat diplomatis.

\section{Strategi Return}

Respon pujian dengan cara mengembalikan pujian tersebut kepada pemberi pujian. Pembelajar bahasa Jepang menggunakan strategi ini untuk merespon pujian dalam situasi situasi \#1 sebanyak dua tuturan, situasi \#5, situasi \#11, situasi \#13 dan situasi \#16 masing-masing satu tuturan.

Berikut adalah contoh percakapan dengan Situasi \#11 : Dalam acara karya wisata kenalan teman anda memuji anda karena anda orangnya sangat humoris.
(PBJ 9)

$$
\begin{aligned}
\text { PSan : } & \begin{array}{l}
\text { Anata wa omoshiroi hito } \\
\text { desune. }
\end{array} \\
\text { Anata : } & \begin{array}{l}
\text { Soudesuka. P san mo } \\
\text { omoshiroi hito dato } \\
\text { omoukedo. }
\end{array}
\end{aligned}
$$

Terjemahan :

$$
\begin{aligned}
\text { Tuan P : } & \text { Kamu orangnya } \\
\text { humoris ya. } & \\
\text { Anata : } & \text { Oh begitu? Menurut } \\
& \text { saya saudara P juga } \\
& \text { orang yang humoris. }
\end{aligned}
$$

Pada data di atas, sebagai pembuka penutur menanyakan kebenaran pujian yang diutarakan, namun yang menjadi inti dari tuturan di atas yaitu panutur kembali memuji pemberi pujian.

Penutur asli bahasa Jepang menggunakan strategi ini untuk merespon pujian pada situasi \#4 enam tuturan, situasi \#2, situasi \#5 dan situasi \#11 tiga tuturan, dan terakhir situasi \#9 satu tuturan.

Situasi \#6. Kenalan teman anda memuji kemampuan anda dalam bermain tenis.

$$
\begin{array}{ll}
\text { (PABJ 11) } & \\
\text { PSan : } & \begin{array}{l}
\text { Tenisu ga jyouzu } \\
\text { desu ne. } \\
\text { Arigatou! Demo P san no } \\
\text { houga puro mitai dayo. }
\end{array} \\
\text { Terjemahan : } & \begin{array}{l}
\text { Pintar sekali main } \\
\text { tenisnya. Seperti atlit } \\
\text { profesional. } \\
\text { Terima kanih, tapi } \\
\text { saudara P jauh yang }
\end{array} \\
\text { Anda : } &
\end{array}
$$


lebih mirip pemain profesional.

Pada data di atas, penutur mengucapkan terima kasih, namun ucapan terima kasih bukan berarti penutur menerima pujian yang diutarakan, melainkan pembuka percakapan yang menjadi inti tuturan adalah kalimat "P san no houga puro mitai dayo". Ini berarti penutur balik memuji pemberi pujian tanpa menerima atau menolak pujian dengan jelas.

\section{Strategi Question}

Strategi ini merupakan respon yang diberikan berupa pertanyaan yang mempertanyakan kebenaran pujian yang diberikan. Pembelajar bahasa Jepang menggunakan strategi ini untuk merespon pujian dalam situasi \#5 sebanyak 12 tuturan, situasi \#10 dan situasi \#12 lima tuturan, situasi \#11 empat tuturan, situasi \#9 dan situasi \#15 tiga tuturan, situasi \#3, situasi \#17, situasi \#18 dua turturan dan yang paling sedikit situasi \#2, situasi \#6, situasi \#7, dan situasi \#13 masing-masing satu tuturan. Berikut ini adalah contoh ungkapan yang digunakan oleh pembelajar bahasa Jepang pada situasi \#5 Di sebuah pertemuan teman anda memuji penampilan anda.

(PBJ 12)

$\begin{array}{ll}\text { Tomodachi : } & \begin{array}{l}\text { (Anatano Namae) } \\ \text { jyanai? Kawaii. } \\ \text { Betsujin ni mieru } \\ \text { yo. }\end{array} \\ \text { Anata }: \text { Ee? Hontou? lya da. } \\ \text { Anta koso futsuu } \\ \text { ni kawaii yo. }\end{array}$

Terjemahan:

Teman : Ini kamu (Nama)?

Cantiknya. Sampai pangling.

Anda : lya? Benarkah? Tidak suka. Anda juga cantik loh.

Pada data di atas, penutur menanyakan kembali kebenaran pujian yang diucapkan. Dengan menggunakana "ee? Hontou?" dan kata "iyada" (gak suka), bukan berarti penutur menolak pujian yang diutarakan, tetapi lebih menunjukan perasaaan malu.

Penutur asli bahasa Jepang menggunakan strategi ini untuk merespon pujian pada situasi situasi \#9 empat tuturan, situasi \#11 tiga tuturan dan yang paling sedikit situasi \#5, situasi \#6, dan situasi \#7 satu tuturan, dengan contoh ungkapan yang digunakan sebagai berikut:

Situasi \#5: Di sebuah pertemuan teman anda memuji penampilan anda.

(PABJ 12) 
Tomodachi: (anatano namae) jyanai? Kawaii. Betsujin ni mieru yo.

Anata : Hontou ni?

Terjemahan :

Teman : Ini kamu (Nama)? Cantiknya. Sampai pangling

Anda : Benarkah?

Pada data di atas penutur mempertanyakan kembali kebenaran pujian yang diberikan. Ujaran di atas kemungkinan menunjukkan bahwa penutur tidak menyangka akan mendapatkan pujian dari orang yang baru saja dikenalnya dengan hubungan yang tidak terlalu akrab.

\section{Strategi Mengganti Topik Pembicaraan}

Strategi mengganti topik menunjukan bahwa penutur tidak menerima dan menolak isi pujian secara langsung atau secara keseluruhan, namun untuk menghindar diganti dengan mengalihkan topik pembicaraan. Pembelajar bahasa Jepang menggunakan strategi ini untuk merespon pujian yang disampaikan pada situasi \#3 Dipuji oleh teman mengenai belajar sebelum ujian

(PBJ 13)

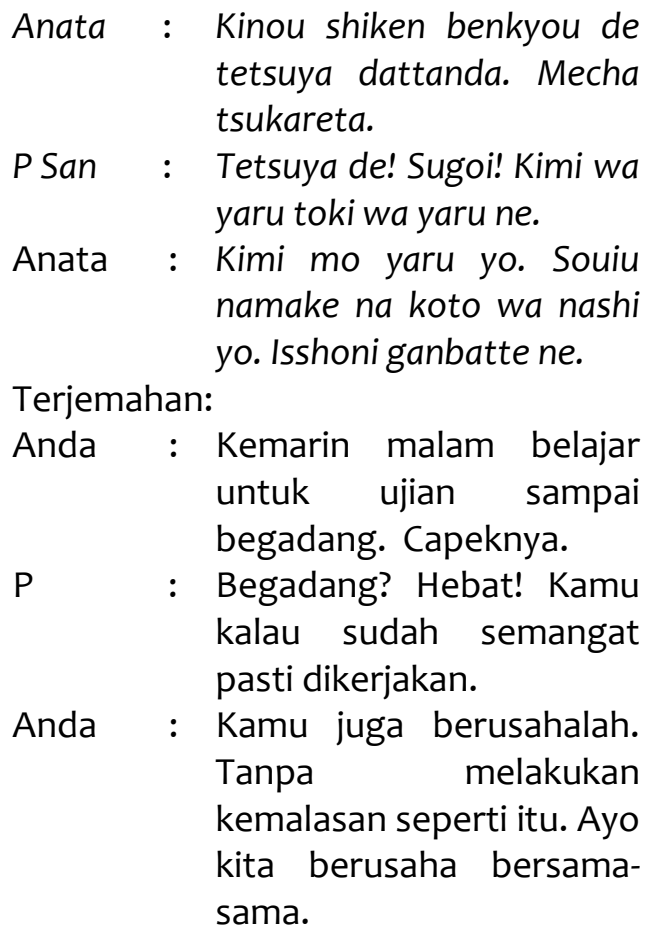

Pada kalimat terlihat penutur tidak menerima atau menolak isi pujian, tetapi mengalihkan pembicaraan dan memberikan semangat kepada pemberi pujian agar berusaha bersama-sama.

Penutur asli bahasa Jepang menggunakan strategi ini untuk merespon pujian pada situasi \#12 Kemampuan memasak anda dipuji oleh dosen pada saat pesta. Strategi ini hanya muncul satu kali.

(PABJ 13)

Tomodachi : Waa!! Kore, Totemo oishii desu yo.

Anata : Tabetai!! Tabetai!!

Terjemahan :

Tomodachi : Wa! Ini sangat enak sekali loh. 
Anda $\quad$ Ingin makan! Ingin
makan!

Dari data di atas, terlihat penutur tidak menerima atau menolak isi pujian, namun mengalihkan tema pembicaraan dengan mengutarakan bahwa penutur ingin makan.

\section{Kategori Scale Down}

Scale down berarti merespon pujian dengan mencegah tinggi hati dan atau menunjukan kerendahan hati. Scale down dilakukan dengan cara memberikan komentar yang menunjukan bahwa pujian tersebut tidak sesuai. Pembelajar menggunakan strategi ini untuk merespon pujian yang diberikan dalam berbagai situasi namun penggunaannya tidak begitu banyak. Misalnya dalam situasi \#13 dua tuturan, sedangkan pada situasi \#3, situasi \#4, situasi \#6, dan situasi \#14 satu tuturan.

Berikut ini adalah contoh ungkapan yang dikemukakan oleh pembelajar bahasa Jepang pada situasi \#14. Sikap anda yang rajin belajar dipuji oleh kenalan teman anda.

(PBJ 14)

Anata: Kinou shiken benkyou de
tetsuya dattanda. Mecha
tsukareta.

P San : Tetsuya de! Sugoi! Kimi wa yaru toki wa yaru ne.

Anata: Shikata arimasen yo. Sou shinakattara komarimasu.

Terjemahan :

Anda : Kemarin malam belajar untuk ujian sampai begadang. Capeknya.

P : : Begadang? Hebat! Kamu kalau sudah semangat pasti dikerjakan.

Anda : Apa boleh buat. Kalo tidak begitu pasti akan pusing.

Pada data di atas penutur tidak menolak maupun menerima secara langsung namun penutur mengatakan "apa boleh buat" untuk menunjukan bahwa pujian itu tidak begitu sesuai.

Penutur asli bahasa Jepang lebih banyak menggunaka strategi scale down untuk merespon pujian. Ini dapat terlihat dari respon yang diberikan diberbagai situasi. Seperti dalam situasi situasi \#14 13 tuturan, sedangkan pada situasi \#3, situasi \#8 tujuh tuturan, sitausi \#12 tiga tuturan, situasi \#5, situasi \#11 dan situasi \#16 dua tuturan dan tuturan paling sedikit situasi \#6, situasi \#7, situasi \#9, situasi \#17, dan situasi \#18 satu tuturan.

Misalnya pada situasi \#3 Dipuji oleh teman mengenai belajar sebelum ujian. 
(PABJ14)

Anata: Kinou shiken benkyou de tetsuya dattanda. Mecha tsukareta.

PSan : Tetsuya de! Sugoi! Kimi wa yaru toki wa yaru ne.

Anata : Demo, zezen atama ni haittenai.

Terjemahan :

Anda : Kemarin malam belajar untuk ujian sampai begadang. Capeknya.

P : Begadang? Hebat! Kamu kalau sudah semangat pasti dikerjakan.

Anda : Tapi, sama sekali tidak masuk ke kepala.

Pada data di atas, penutur tidak menolak maupun menerima secara langsung namun penutur mengatakan apa yang menjadi objek pujian tidak sesuai dengan kenyataannya.

\section{Strategi Tertawa}

Respon yang diberikan dengan tidak menunjukan respon secara verbal, yaitu memberikan repon secara nonverbal dengan tersenyum. Sebuah senyuman memiliki arti yang susah ditebak. Pembelajar bahasa Jepang tidak menggunakan strategi ini dalam merespon pujian.

Berbeda dengan pembelajar bahasa Jepang, penutur asli bahasa Jepang menggunakan strategi tertawa atau tersenyum dalam lima situasi, yaitu pada situasi \#3, situasi \#5, situasi \#7, situasi \#11 dan situasi \#16. Dengan contoh ungkapan seperti di bawah ini.

Situasi \#3 Dipuji oleh teman mengenai belajar sebelum ujian.

(PABJ 15)

Anata: Kinou shiken benkyoude tetsuya dattanda. Mecha tsukareta.

P San : Tetsuyade! Sugoi! Kimiwa yaru tokiwa yarune.

Anata: Hahaha.

Terjemahan :

Anda : Kemarin malam belajar untuk ujian sampai begadang. Capeknya.

P : : Begadang? Hebat! Kamu kalau sudah semangat pasti dikerjakan.

Anda : (tertawa)

Dalam data di atas penutur hanya tersenyum. Sedangkan menerima dan menolak pujian tidak begitu terlihat.

\section{Strategi Malu atau Terkejut}

Respon yang diberikan menunjukan bahwa penutur tidak menyangka akan mendapatkan pujian dan malu. Pembelajar bahasa Jepang tidak begitu banyak menggunakan strategi ini, hanya muncul empat tuturan pada situasi \#7, situasi \#10, situasi \#14 dan situasi \#17. 
Situasi \#7 Dalam sebuah pementasan seni kemampuan menyanyi anda dipuji oleh dosen.

(PBJ 15)

C Sensei : Kimi wa igaito uta ga jyouzu desune.

Anata : Ee, Sonna fuu ni iwareru to hazukashii desu.

Terjemahan :

C Sensei : Kamu ternyata pintar bernyanyi ya.

Anda : lya. Wah kalau dibilang begitu jadi malu.

Pada data di atas hubungan jarak sosial dengan pemberi pujian tidak jelas terlihat namun dari ungkapan yang dituturkan penutur tidak menerima atau menolak pujian yang diberikan, namun cenderung menghindar dengan menuturkan ungkapan yang mengandung perasaan malu.

Penutur asli bahasa Jepang tidak banyak menggunakan strategi malu dan terkejut dalam merespon pujian. Strategi malu dan terkejut muncul dua kali pada situasi \#7 dan situasi \#10.

Situasi \#7. Dalam sebuah pementasan seni, kemampuan menyanyi anda dipuji oleh dosen.

(PABJ 16)

CSensei : Kimi wa igaito uta ga jyouzu desu ne.

$$
\begin{array}{lll}
\text { Anata } & \text { Hontou desuka. } \\
& \text { Hazukashii. } \\
\text { CSensei : } & \text { Kamu ternyata pintar } \\
& \text { bernyanyi ya. } \\
\text { Anda : } & \text { Benarkah? Waa malu.. }
\end{array}
$$

Pada data di atas, hubungan jarak sosial dengan pemberi pujian tidak jelas terlihat. Dari ungkapan yang dituturkan, penutur tidak menerima atau menolak pujian yang diberikan, namun cenderung menghindar dengan menuturkan ungkapan yang mengandung perasaan malu. Pada awal tuturan, penutur menanyakan kembali kebenaran pujian yang diutarakan.

\section{Kesimpulan}

Dari hasil penelitian terdapat persamaan dan perbedaan strategi merespon pujian antara pembelajar bahasa Jepang dan penutur asli bahasa Jepang.

Adapun persamaan dalam merespon pujian, peserta menggunakan strategi terima kasih untuk merespon pujian yang disampaikan oleh teman. Peserta secara keseluruhan menggunakan strategi merespon pujian yang sama, yaitu strategi terima kasih dan strategi ungkapan tidak setuju. Penggunaan strategi ungkapan 
persetujuan untuk merespon pujian dari teman yang akrab juga ditemukan di sini.

Baik pembelajar bahasa Jepang maupun penutur asli bahasa Jepang menggunakan strategi ungkapan bahagia untuk merespon pujian pada situasi \#12, yaitu pada saat dipuji oleh dosen yang akrab saat pesta, tetapi penutur asli bahasa Jepang lebih banyak menggunakan strategi ini pada situasi lain dibandingkan dengan pembelajar bahasa Jepang. Terdapat pula peserta yang menggunakan strategi penolakan untuk merespon pujian yang berasal dari teman yang baru kenal dan tidak akrab. Penggunaan strategi comment acceptence untuk merespon pujian terlihat pada situasi \#17, yaitu pada saat anda dipuji oleh dosen karena menjadi relawan panti Jompo.

Terdapat pula perbedaan strategi yang digunakan oleh peserta dalam merespon pujian. Yang pertama, strategi yang digunakan penutur asli bahasa Jepang lebih banyak dibandingkan dengan pembelajar bahasa Jepang. Kedua, Pembelajar bahasa Jepang tidak ada yang menggunakan strategi reassignment dalam merespon pujian. Sebaliknya penutur asli menggunakan strategi ini untuk merespon pujian.

Ditemukan bahwa pembelajar bahasa Jepang tidak ada yang menggunakan strategi tertawa dalam merespon pujian. Tetapi, penutur asli bahasa Jepang menggunakan strategi ini untuk merespon pujian.

Banyaknya persamaan antara strategi merespon pujian yang digunakan oleh pembelajar bahasa Jepang dan penutur asli bahasa Jepang dipengaruhi oleh kedekatan budaya antara Jepang dan Indonesia, karena Indonesia dan Jepang merupakan negara Asia yang masih memiliki latar budaya yang dekat dan masih menjunjung konsep Timur.

\section{Daftar Pustaka}

Alwasilah, A. C. (2008). Pokoknya Kualitatif. Jakarta: Pustaka Jaya.

Brown, G., \& Yule, G. (1996). Discourse Analisys (Analisis Wacana). Jakarta: PT. Gramedia Pustaka Utama.

Blum-Kulka et al. (1989). Cross-Cultural Pragmatics: Requests and Apologies. Norwood, NJ: Ablex Publishing Corporation. 
Korsatianwon, Sayan.(2003. Homekotoba

ni taisuru hentou sutairu

hikaku.Jepang : Nihongo Kyoiku 124 Gou.

Levison, S., C. (1983). Pragmatics.

Cambridge: Cambridge University

Press

Nadar, F.X. (2009). Pragmatik dan

Penelitian Pragmatik. Yogyakarta:

Graha Ilmu.

Rosiah, Rosi. (2017). Respon terhadap pujian pembelajar bahasa Jepang. Yogyakarta: Journal Of Japanese Education and Linguistics Vol 01. 